\title{
Sistem Informasi Geografis Pemetaan Sebaran Data Covid-19 Pada Puskesmas Kerongkong Kabupaten Lombok Timur Berbasis Web
}

\author{
Imam Fathurrahman ${ }^{1 *}$, Moh. Farid Wajdii ${ }^{2}$, Hadian Mandala Putra ${ }^{3}$, Baiq Vinaru Widarina ${ }^{4}$ \\ ${ }^{124}$ Program Studi Teknik Informatika, Universitas Hamzanwadi \\ 3Program Studi Teknik Komputer, Universitas Hamzanwadi \\ *i.fathurrahman@hamzanwadi.ac.id
}

\begin{abstract}
Abstrak
Sistem informasi merupakan sekumpulan data atau fakta yang diproses dan diolah sedemikian rupa sehingga menghasilkan sesuatu yang bisa dipahami dan dapat bermanfaat bagi penerimanya. Dikalangan masyarakat umum, kebutuhan akan sebuah informasi yang akurat dan cepat sangat dibutuhkan saat ini, khususnya informasi mengenai penyebaran penyakit Covid-19 yang melanda dunia saat ini. Covid-19 (Coronavirus) adalah virus yang dapat menyerang saluran pernapasan dan bisa menular ke siapa saja melalui percikan dahak (droplet). Akan tetapi, dalam penyampaian informasi yang dilakukan petugas puskesmas kerongkong mengenai wilayah penyebaran Covid-19 di kecamatan suralaga masih menggunakanmetode sosialisasi. Metode ini dinilai tepat sasaran, namun dirasa kurang efektif bagi desa yang memiliki angka penyebaran yang cukup tinggi di kecamatan suralaga. Oleh karena itu, dibutuhkan sistem informasi Pemetaan Wilayah Penyebaran Covid-19 yang cepat dan akurat dalam menyampaikan informasi kepada masyarakat, tujuannya agar pihak puskesmas lebih mudah dalam melakukan tindakan yang preventif terhadap wilayah yang memiliki angka penyebaran yang cukup tinggi dengan melihat lokasi wilayah penyebaran di kecamatan suralaga. WebGis merupakan sistem informasi geografis berbasis web yang terdiri dari beberapa komponen yaitu desain grafis pemetaan, peta digital dengan analisis geografis, programan komputer, dan sebuah database yang saling berubungan menjadi satu bagaian. Dalam penyusunan tahapanpenelitian ini dilakukan dengan carapengumpulan data, perancangan system, tahap pembuatan system, pengujian dan evaluasi.Adanya WebGis pemetaan lokasi pasien dapat membantu pihak puskesmas kerongkong dalam dalam melakukan pendataan pasien Covid-19 serta dapat dengan cepat memberikan informasi kepada masyrakat
\end{abstract}

Kata Kunci : Web, Covid-19, Sistem Informasi Geografis

\begin{abstract}
An information system is a collection of data or facts that are processed and processed in such a way as to produce something that can be understood and can be useful for the recipient. Among the general public, the need for accurate and fast information is urgently needed at this time, especially information regarding the spread of the Covid-19 disease that is hitting the world today. Covid-19 (Coronavirus) is a virus that can attack the respiratory tract and can be transmitted to anyone through droplets of phlegm. However, in conveying information by the Kerongkong Health Center officers regarding the Covid-19 distribution area in the Suralaga sub-district, they still use the socialization method. This method is considered right on target, but it is considered less effective for villages that have a fairly high distribution rate in the Suralaga sub-district. Therefore, an information system for Mapping the Covid-19 Spread Area is needed that is fast and accurate in conveying information to the public, the goal is to make it easier for the puskesmas to take preventive actions against areas that have a fairly high spread rate by looking at the location of the distribution area in the sub-district. suralaga. WebGIS is a web-based geographic information system consisting of several components, namely mapping graphic design, digital maps with geographic analysis, computer programs, and a database that are interconnected into one part. In the preparation of the stages of this research carried out by means of data collection, system design, system creation stage, testing
\end{abstract}


and evaluation. The existence of WebGIS mapping the patient's location can help the throat health center in collecting data on Covid-19 patients and can quickly provide information to the public.

Keywords: Web, Covid-19, Geographic Information System.

\section{Pendahuluan}

Saat ini kebutuhan masyarakat akan informasi semakin banyak seiring kemajuan teknologi dan mudahnya mengkases informasi melaui internet. Informasi penyebaran covid-19 merupakan hal yang penting bagi masyarakat saat ini, mengingat banyak korban yang meninggal maupun yang masih dalam perawatan.

Pandemi COVID-19 (Coronavirus disease 2019) telah melanda dunia selama kurang lebih 2 tahun merupakan penyakit yang disebabkan oleh jenis Coronavirus baru yaitu Sars-Cov-2 yang dilaporkan kali pertama di wuhan tiongkok pada tanggal 31 desember 2019[1]. Pada tanggal 2 maret 2020 Covid-19 mulai mewabah di indonesia dengan kasus pertama berjumlah dua kasus. sedangkan menurut satuan gugus tugas (Satgas) dalam menangani Covid-19 pada tanggal 4 juli 2020 tercatat 60.695 kasus dan 3.036 korban jiwa.

Adapun dampak dari virus yaitu menyerang saluran pernafasan, yang dapat berakibat ringan seperti flu dan bisa berakibat terinfeksi berat seperti infeksi paru-paru (pneumonia) yang dimana virus ini dapat menular dari manusia ke manusia melalui percikan dahak (droplet)[2].

Dari jumlah pasein yang terpapar penyakit Covid19 yang terjadi dari hari ke hari di kecamatan suralaga, menyebabkan angka penyebaran di wilayah tersebut semakin mengalami peningkatan dengan melihat jumlah penyebaran penyakit Covid-19 di kecamatan suralaga semakin meningkat, pemerintahpun mengambil tindakan PSBB (Pembatasan Sosial Bersekala Besar) bagi desa-desa yang memiliki angka penyebaran yang cukup tinggi. Untuk mengurangi angka penyebaran Covid-19 dikecamatan suralaga, sangat penting sekali pihak puskesmas kerongkong untuk mengetahui lokasi pasein yang terpapar penyakit Covid-19 agar pihak puskesmas bisa melakukan tindakan yang preventif bagi pasien yang terpapar penyakit Covid-19 di desa tersebut.

Namun permasalahan yang dialami oleh pihak puskesmas kerongkong saat ini yaitu kurangnya sistem pengawasan yang intensif dari pihak puskesmas untuk mengontrol dan memantau masyarakat yang terkena atau terpapar penyakit Covid-19 berdasarkan lokasi pasien di kecamatan suralaga. Untuk menyelesaikan permasalahan tersebut, dibutuhkan sebuah sistem informasi yang mampu memberikan informasi titik-titik pesebaran Covid-19 khususnya pada kecamatan suralaga, dimana informasi tersebut bukan hanya diperuntukan bagi pihak puskesmas tetapi juga 
dapat dimanfaatkan sebagai informasi bagi masyarakat umum.

\section{Tinjauan Pustaka}

\subsection{Penelitian Terkait}

Aris Sudianto, Nurhidayati, dan Lalu Kerta Wijaya yang berjudul "Penerapan sistem informasi Geografis untuk pemetaan bengkel tambal ban di kecamatan Selong Kabupaten Lombok Timur": 2019. Teknologi Gis kini dapat dimanfaatkan untuk memajukan para pelaku usaha kecil seperti bengkel tambal ban yang sangat butuh sentuhan teknologi agar keberadaan usaha mereka lebih diketahui oleh masyarakat luas[3][4].

Imam Fathurahman dan L.M Samsu yang berjudul "Pendataan Mitra Produk Herbal CV.Rinjani Tirta Lombok Timur Berbasis Geographic Information System (GIS)": 2021. Penelitian ini bertujuan untuk memudahkan konsumen dalam mencari mitra yang menjual produk herbal dari CV. Rinjani Tirta yang berada di Lombok Timur[5].

M.Wasil, L.Samsu, dan Y.K.Putra,"Sistem Informasi Geografis untuk pemetaan Homestay di Lombok Timur Berbasis Android": 2020. Keterbatasan informasi tentang tujuan menginap, objek penginapan yang menarik, objek honymoon yang indah, serta rute untuk mencapai suatu kawasan penginapan menjadi masalah yang dialami calon wisatawan sehingga banyak yang memilih menggungakan guide. Dari itu penulis membuat sistem informasi geografis pemetaan homestay di lombok timur berbasis android[6]. Ilka Zufria, Septiana Dewi Andriana, Muhammad Zulfikar Lubis yang berjudul "Sistem Informasi Geografis Lahan Pertanian Pada Kecamatan Bandar Khalifah Berbasis Pemetaan" : 2019. ArcView GIS merupakan salah satu perangkat lunak yang berguna sebagai pemetaan suatu wilayah. ArcView GIS telahmemiliki database dan bahasa pemograman tersendiri sebagai pengolahdata spasial dan data non-spasial. Hal ini menjadikan ArcView GIS sebagaisebuah pilihan yang tepat untuk pembuatan sistem informasi geografislahan pertanian khususnya berbasis pemetaan[7].

Nelfira, Almuharnis, Angga Wirma Yudha Putra, yang berjudul. "Sistem Informasi Geografis Pemetaan Sekolah (Scool Mapping) Berbasis Web Gis Pada UPT Dinas Pendidikan Kecamatan Padang Utara": 2018. Dimana penelitian ini bertujuan bertujuanmembangun suatu aplikasi sistem informasi geografis,sehingga dapat memberikaninformasi yang berguna mengenai lokasi sekolah yang ada di UPT Dinas PendidikanKecamatan Padang Utara.Adanya Sistem ini, pengguna lebih mudah mendapatkan informasi sekolah dan semua pengguna dapat mengakses sistem dengan mudah. Sistem yang dibuat meliputi sebaran, rute antar sekolah, cari sekolah yang dituju dan sekolah terdekat dari posisi user berada[8]. 
Ionia Veritawati, Steffia Nova, Riadika Mastra, yang berjudul "Sistem Informasi Pemetaan Penyakit Demam Berdarah Berbasis Informasi Geografis": 2020. Dimana penelitian ini bertujuan mengatasi masalah kesehatan yang seringterjadi di Indonesia adalah demam berdarah dengue (DBD), khususnya di kecamatan Tambun Selatan. Aplikasi ini digunakan Untuk memberikan informasi perihal pemetaan penyebaran penyakit demam berdarah tersebut. Sistem ini dibang untuk dapat mengintegrasikan data spasial berupa petawilayah Tambun Selatan dengan data dan informasitematikyang berupa data penderita demam berdarah dan datakasus-kasus DBD per tahun dalam bentuk tabel maupungrafik[9].

Febriansyah Marwan, Dodi Hidayat, dan Budi, yang berjudul "Sistem Informasi Pemetaan dan Penyuluhan Covid-19 Pada Dinas Komunikasi dan Informatika Di Kabupaten LabuhanBatu Utara": 2020. Dimana sistem informasi ini dibuat dalam bentuk web pemetaan dan webgis yang dapat membantu instansi dinas komunikasi dan informatika kabupaten labuhanbatu utara dalam menyampaikan informasi yang cepat dan ukurat kepada masyarakat kabupaten labuhanbatu utara[1].

\subsection{Landasan Teori}

\section{Pengertian Sistem}

menerangkan sistem adalah sistem adalah satu kesatuan komponen yang saling terhubung dengan batasan yang saling terhubung dengan batasan yang jelas bekerja bersama-sama untuk mencapai seperangkat tujuan[10].

\section{Pengertian Informasi}

Informasi merupakan data atau pakta yang telah diproses sedemikian rupa, sehingga merubah bentuknya menjadi informasi. Disamping itu informasi dapat mengurangi ketidakpastian serta mempunyai nilai dalam keputusan karena denga adanya informasi kita dapat memilih tindakantindakan dengan resiko paling kecil. Sedangkan pengertian informasi menurut MC Leod (1995) adalah salah satu jenis utama sumber daya yang tersedia bagi manajer, yang pengelolaannya menggunakan peralatan komputer yang digunakan untuk memecahkan masalah yang sedang dihadapi dengan segera[10][11].

\section{Sistem Informasi}

Sistem informasi didefinisikan sebagai sistem didalam suatu organisasi dalam suatu organisasi yang merupakan kombinasi dari orang-orang, fasilitas, media, prosedur-prosedur dan pengendalian yang ditunjukan untuk mendapatkan jalur komunikasi penting, memproses tipe transaksi rutin tertentu memberi sinyal kepada menejemen dan yang lainnya terhadap kejadian-kejadian internal dan eksternal yang penting dan menyediakan suatu dasar informasi untuk pengambilan keputusan yang cerdik[12]. 


\section{SIG ( Sistem Informasi Geografis)}

Sistem Informasi Georafis (SIG) atau Georaphical Information System (GIS) merupakan suatu sistem informasi yang berbasis komputer, dirancang untuk bekerja dengan menggunakan data yang memiliki informasi spasial (bereferensi keruangan). Sistem informasi geografis dapat meng-capture, mengecek, mengintegrasikan, memanipulasi, menganalisa, dan menampilkan data yang secara spasial mereferensikan kepada kondisi bumi. Sistem Informasi Geografis juga didefinisikan sebagai Sistem informasi yang digunakan untuk memasukkan, menyimpan, memanggil kembali, mengolah, menganalisis, dan menghasilkan data bereferensi geografis atau data geospasial, untuk mendukung pengambilan keputusan dalam perencanaan dan pengelolaan penggunaan lahan, sumber daya alam, lingkungan, transportasi, fasilitas kota, dan pelayanan umum lainnya[20].

\section{Covid-19}

Word Health Organization (WHO) menjelaskan bahwa Coronavirus (COV) adalah virus yang menginfeksi sistem pernapasan. Infeksi virus ini disebut COVID-19. Virus Corona menyebabkan penyakit flu biasa sampai penyakit yang lebih parah seperti Sindrom pernapasan timur tengah (MERS-CoV) dan sindrom pernapasan akut parah (SARS-COV). Virus Corona adalah zoonotic yang artinya ditularkan antara hewan dan manusia. Berdasarkan kementerian kesehatan indonesia, perkembangan kasus COVID-19 di wuhan berawal pada tanggal 30 desember 2019 dimana wuhan Municipal Health Committee mengeluarkan pernyataan "urgent notice on the treatment of pneumonia of unknown cause". Penyebaran virus Corona ini sangat cepat bahkan sampai ke lintas negara[13].

6. Pemetaan

Pemetaan adalah pengelompokkan suatu kumpulan wilayah yang berkaitan dengan beberapa letak geografis wilayah yang meliputi dataran tinggi, pengunungan, sumber daya dan potensi penduduk yan berpengaruh terhadap sosial kultural yang memiliki ciri khas khusu dalam penggunaan skala yang tepat[5].

7. Website

Website atau situs dapat diartikan sebagai kumpulan halaman-halaman yang digunakan untuk menampilkan informasi text, gambar diam atau bergerak, animasi, suara, dan atau gabunan dari semuanya, baik bersifat statis maupun dinamis yang membentuk suatu rangkaian bangunan yang saling terkait, yang masingmasing dihubungkan dengan jaringan-jaringan halaman[14].

\section{Codeigniter}

Codelgniter adalah sebuah framework PHP yang dapat membantu mempercepat developer dalam pengembangan aplikasi web berbasis PHP di bandingkan jika menulis semua kode program dari awal. Codelgniter pertama kalai dibuat oleh 
Rick Ellis, CEO Ellislab,Inc, sebuah perusahaan yang memproduksi CMS (Content Management System) yang cukup handal, yaitu Expression Engine.

Codelgniter adalah framework PHP yang dibuat berdasarkan kaidah Model-View-Conroller. Dengan MVC, maka memungkinkan pemisahan antara layer application-logic dan presentation.

Framework adalah kerangka kerrja. Framework juga dapat diartikan sebagai kumpulan skrip (terutama class dan function) yang dapat membantu programmer dalam menangani berbagai masalah. Diantaranya adalah koneksi ke basis data, pemanggilan variabel, file, dan lainlain sehingga developer bisa lebih fokus dan lebih cepat membangun aplikasi[15].

\section{Leaflet.Js}

Leaflet merupakan library javascript open source yang berguna untuk membangun aplikasi peta interaktif berbasis web. Leaflet support dengan platform mobile dan platform desktop, HTML5 dan CSS3 serta OpenLayer dan Google Maps Api yang merupakan library javascript untuk membangun aplikasi peta yang sangat populer saat ini. Dengan memanfaat leaflet, developer yang ditidak memiliki latar belakang GIS pun dapat dengan mudah menampilkan peta interaktif berbasis web pada server. Leaflet mampu menampilkan layer dari file Geojson, memberi style dan membuat layer yang intraktif seperti menampilkan marker yang menampilkan PopUp informasi ketika di klik[16].

10. Xampp

Xampp juga sering diartikan sebagai layanan data pada web browser. Fungsi dari web server sebagai penerimaan permintaan brupa halaman client dan mengeriman kembali hasil yang diminta dalam bentuk halaman web. Dengan menginstal paket Xampp maka sekali instal anda sudah mendapatkan program PHP, Mysql dan Apache[17].

11. PHP

PHP (Hypertext Preprocessor) yaitu bahasa pemrograman web server-side yang bersifat open source. PHP merupakan script terintegrasi dengan HTML dana berada pada servver (server side HTML embedded scripting). PHP adalah scrip yang digunakan untuk membuat halaman website yang dinamis. Dinamis berarti halaman yang akan ditampilkan dibuat saat halaman itu diminta oleh client. Mekanisme ini menyebabkan informasi yang di terima client selalu terbaru. Semua script PHP dieksekusi pada server dimana script tersebut dijalankan[18].

12. Sublime Text3

Sublime Text adalah teks editor berbasis phyton yang cukum terkenal dikalangan pengembang, penulis, dan desainer. Sublime Text mencegah plugin merusak sublime text dan mempercepat pembukaan aplikasi di awal[19].

13. Mysql 
MySQL menggunakan bahasa SQL (Structured Query Language) adalah bahasa standar yang digunakan untuk mengakses server database. Jadi, MYSQL adalah Software nya dan SQL adalah bahasa perintahnya. MySQL juga dapat berjalan pada personal komputer (banyak pengembang dari MySQL terjadi pada system yang tidak mahal. Yaitu linux system)[20].

\subsection{Tahap Penelitian}

Pada tahapan ini penulis melakukan penelitian dengan beberapa tahap :

1. Tahap Pengumpulan Data

Dalam tahapan ini proses pengumpulan informasi mengenai data-data yang dibutuhkan dalam membuat sistem informasi pemetaan penyakit covid-19 dipuskesmas kerongkong.

2. Tahap Perancangan Sistem

Dalam perancangan sistem ini meliputi: analisa dan pengumpulan data terhadap kebutuhan dalam pembuatan sistem diproject ini seperti perancangan database, dan perancangan website pemetaan covid-19.

3. Tahap Pembuatan Sistem

Dimana pada tahapan ini, dilakukan proses pembuatan website pemetaan covid-19.

4. Tahap Pengujian dan Evaluasi

Tahap ini dilakukan pengujian sistem dan menganalisa sistem informasi pemetaan covid-19 apakah bisa berjalan dan berfungsi dengan baik, dan jika terdapat kesalahan bisa dilakukan perbaikan

Tahap Pengumpulan data

Tahap Perancangan Sistem

\section{Tahap Pengujian dan Evaluasi}

\section{Gambar 1 : Tahapan Penelitian}

\section{Metode Penelitian}

\subsection{Metode dalam penelitian}

Metode pengumpulan data dalam penyusunan penelitian ini dilakukan dengan cara:

\section{Observasi}

Metode ini merupakan metode pengumpulan data dengan melakukan pengamatan langsung ke lokasi penelitian yaitu puskemas kerongkong dengan objek yang diteliti untuk mengumpulkan data atau informasi yang berkaitan dengan permasalahan yang ada, seperti data Covid-19 dan data mengenai profile puskemas kerongkong.

2. Wawancara

Wawancara adalah suatu cara untuk mengumpulkandata-data dengan mengajukanpertanyaan-pertanyaan langsung 
kepada kepala puskesmas kerongkong sebagai informan yang ahli atau yang berwenang dalam suatu masalah.

3. Studi Pustaka

Metode ini merupakan metode melakukan pengumpulan data yang berarah pada pencarian data dan informasi melalui dokumen-dokumen, jurnal-jurnal, dan ebook sebagai pendukung atau pelengkap dalam proses penelitian ini.

\subsection{Lokasi Penelitian}

Penelitan ini berlokasi di Puskesmas Kerongkong yang terletak di desa kerongkong kecamatan suralaga, kabupaten Lombok timur, Provensi Nusa Tenggaran Barat, Indonesia. Penelitian ini dilakukan dari bulan april sampai dengan bulan agustus 2021.

\subsection{Pengumpulan Bahan}

Dalam proses pembuatan Sistem Informasi Pemetaan Wilayah Penyebaran Covid-19 pada Puskesmas Kerongkong Kecamatan Suralaga perangkat keras dan perangkat lunak yang dibutuhkan yaitu :

1. Perangkat Keras (Hardware) merupakan suatu komponen yang sangat dibutuhkan dalam mewujudkan sistem yang diusulkan. Adapun hardware yang dibutuhkan dalam membuat dan menjalankan sistem yang diusulkan adalah seperangkat alat komputer dan spesifikasi sebagai berikut:

a. Processor dengan speed $2 \mathrm{GHz}$

b. Hardisk dengan minimal penyimpanan 500 GB HDD

c. Batrai dengan Rechargeablr Li-Polymer 3000MAh

d. Memori / Ram 2 GB DDR3 \#PC-NB10-A

2. Perangkat Lunak (Software)

Kebutuhan perangkat lunak yang digunakan untuk membuat desain sistem yang baru untuk menjalankan sistem yang baru ini adalah sebagai berikut :
a. Sistem operasi windows 10
b. Xampp
c. Google Crome
d. Sublime Text3

\section{Hasil dan Pembahasan}

1. Halaman Wilayah Pasien

Berikut ini dapat dilihat gambar 2. adalah tampilan Maps Pemetaan Wilayah Penyebaran Covid-19 pada puskesmas kerongkong, fungsinya untuk menampilkan lokasi wilayah penyebaran Covid19 yang di inputkan oleh admin dan yang terdaftar di sistem. 


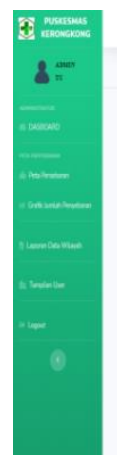

PETA GEOGRAFIS WILYAA PENEEARAN COVID-19

them

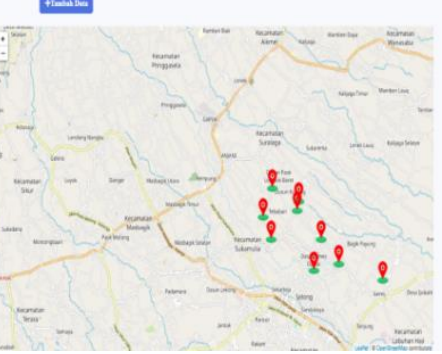

Gambar 2 : Tampilan Maps Wilayah

2. Tampilan Laporan Data Wilayah

Berikut ini adalah tampilan laporan data wilayah penyebaran Covid-19, fungsinya admin bisa melihat secara keseluruhan data wilayah penyebaran Covid-19 yang sudah di inputkan.

Untuk lebih jelasnya dapat dilihat pada gambar 3. di bawah ini.

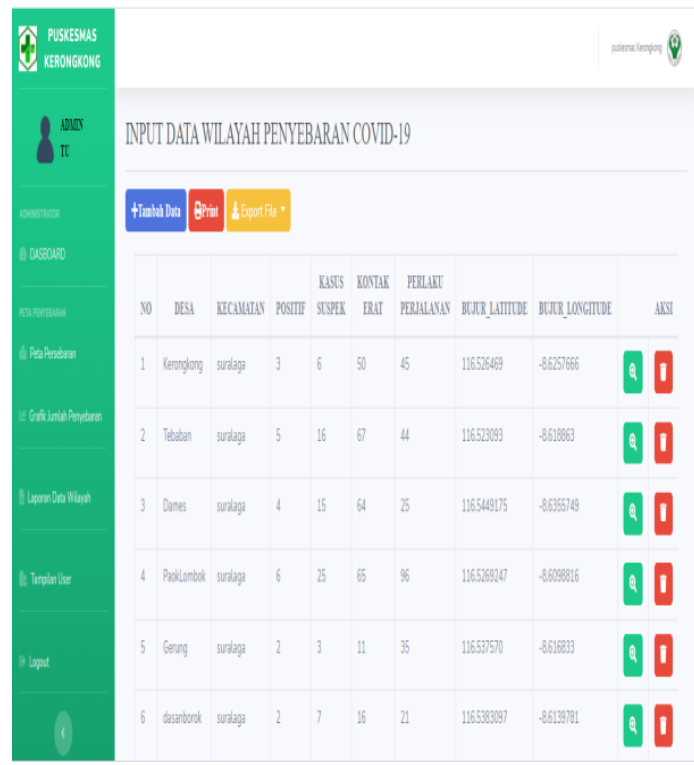

Gambar 3 : Tampilan Laporan Wilayah

3. Tampilan Login Adamin

Terlihat gambar 4. tampilan halaman Login admin pada Sistem Informasi Pemetaan Wilayah Penyebaran Covid-19 Pada Puskesmas Kerongkong Kecamatan Suralaga.

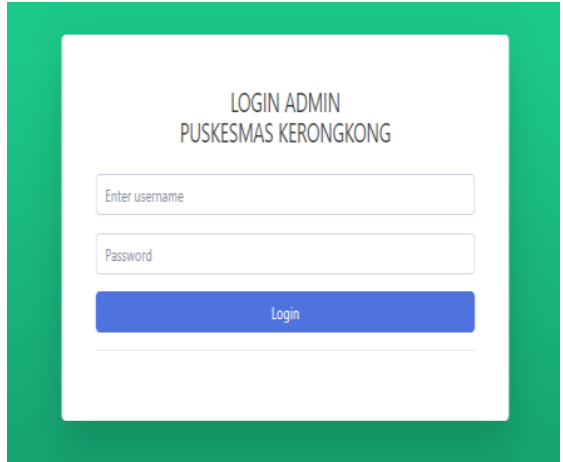

Gambar 4 : Tampilan Login Admin 4. Tampilan Grafik Tampilan pada gambar 5. ini menunjukkan grafik jumlah angka kasus Covid-19 untuk memonitoring jumlah kasus bagi desa-desa yang ada di kecamatan suralaga.

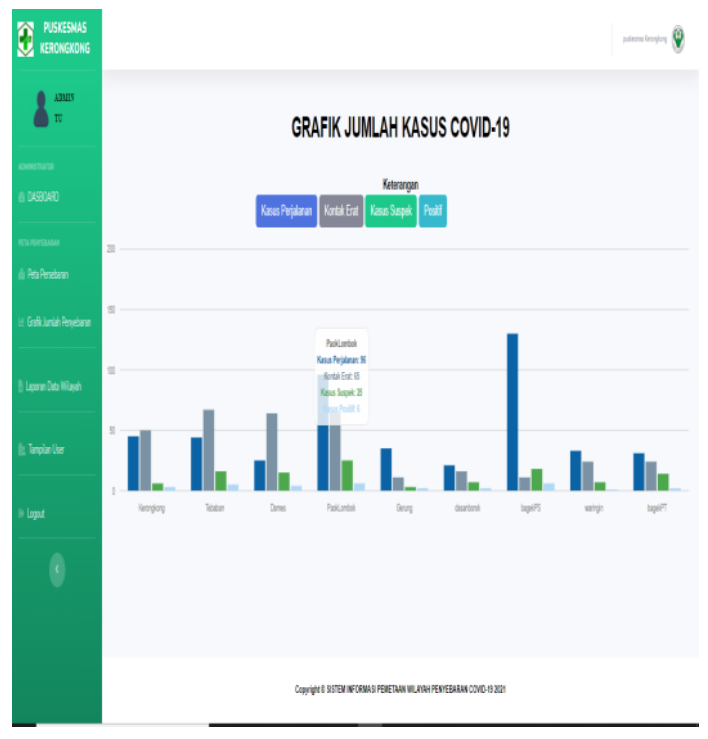

Gambar 5 : Tampilan Grafik 


\section{Kesimpulan}

Berdasarkan penelitan yang dilakukan di puskesmas kerongkong kecamatan suralaga, terdapat hasil yang didapatkan serta pembahasan yang dapat diambil kesimpulan yaitu:

Sistem informasi pemetaan wilayah penyebaran Covid-19 pada puskesmas kerongkong dapat memudahkan pihak puskemas dalam menemukan lokasi pasien secara cepat, guna untuk memudahkan pihak puskesmas dalam mengambil tindakan preventif terhadap pasein yang ada diwilayah tersebut. Sistem informasi ini bisa juga menjadi alat bantu dalam mengolah data dan informasi mengenai Covid-19 mengenai wilayah penyebaran Covid-19 yang ada di kecamatan suralaga.

\section{Daftar Pustaka}

[1] F. Marwan and D. Hidayat, "Sistem Informasi Pemetaan Dan Penyuluhan Covid-19 Pada Dinas Komunikasi Dan Informatika Kabupaten Labuhanbatu Utara," ... Inf. Komun. Ke ..., pp. 431-436, 2020.

[2] A. Susilo et al., "Coronavirus Disease 2019: Tinjauan Literatur Terkini," J. Penyakit Dalam Indones., vol. 7, no. 1, p. 45, 2020, doi: 10.7454/jpdi.v7i1.415.

[3] L. K. W. Sudianto Aris, Nurhidayati, "Penerapan Sistem Informasi Geografis Untuk Pemetaan Bengkel Tambal Ban di
Kecamatan Selong Kabupaten Lombok Timur," Infotek J. Inform. dan Teknol., vol. 3, no. 1, pp. 51-57, 2020, doi: 10.1029/2019GH000237.

[4] S. M. Sudianto Aris, "Penerapan Sistem Informasi Geografis (GIS) dalam Pemetaan Kerajinan Kain Tenun dan Gerabah untuk Meningkatkan Potensi Kerajinan di Kabupaten Lombok Timur," Infotek J. Inform. dan Teknol. J. Inform. dan Teknol., vol. 1, no. 2, pp. 64-71, 2018.

[5] L. M. S. Imam Faturahman, "Infotek: Jurnal Informatika dan Teknologi Pendataan Mitra Produk Herbal CV . Rinjani Tirta Lombok Timur Berbasis Geographic Information System ( GIS ) Program Studi Teknik Informatika , Universitas Hamzanwadi 2 Program Studi Sistem Informasi , Universita," vol. 4, no. 1, pp. 70-78, 2021.

[6] Y. K. P. muhammad wasil, L.M.Samu, "SISTEM INFORMASI GEOGRAFIS UNTUK PEMETAAN HOMESTAY DI LOMBOK TIMUR BERBASIS ANDROID," vol. 3, no. 1, pp. 1-10, 2020.

[7] I. Zufria, S. D. Andriana, and M. Z. Lubis, "Sistem Informasi Geografis Lahan Khalifah Berbasis Pemetaan," JISTech (Journal Islam. Sci. Technol., vol. 4, no. 2, pp. 108-117, 2019.

[8] D. S. Wahyuni, "No Title تتن;," SELL J., vol. 
5, no. 1, p. 55, 2020.

[9] S. Kasus and P. Puskesmas, "Sistem Informasi Pemetaan Penyakit Demam Berdarah Berbasis Informasi Geografis," vol. 1, no. 1, pp. 1-5, 2020.

[10] P. E. Sudjiman and L. S. Sudjiman, "Analisis Sistem Informasi Manajemen Berbasis Komputer Dalam Proses Pengambilan Keputusan," TelKa, vol. 8, no. 2, pp. 55-66, 2020, doi: 10.36342/teika.v8i2.2327.

[11] Sudianto Aris, "Penerapan Website Sebagai Sarana Promosi Wisata Budaya pada Kabupaten Lombok Timur," Infotek J. Inform. dan Teknol., vol. 1Sudianto, no. 1, pp. 11-17, 2018.

[12] A. Jogiyanto, "_Jogiyanto Hartono_ _Google Scholar_." 2005, 398.

[13] D. A. D. Nasution, E. Erlina, and I. Muda, "Dampak Pandemi COVID-19 terhadap Perekonomian Indonesia," J. Benefita, vol. 5, no. 2, p. 212, 2020, doi: 10.22216/jbe.v5i2.5313.

[14] A. Nugroho and W. A. Kusuma, "Sistem Informasi Geografis Pemetaan Lokasi Bird Contest Kota Malang Berbasis Android," Sistemasi, vol. 7, no. 3, p. 212, 2018, doi: 10.32520/stmsi.v7i3.338.

[15] P. S. Hasugian, "Perancangan Website Sebagai Media Promosi Dan Informasi," J. Inform. Pelita Nusant., vol. 3, no. 1, pp.
82-86, 2018.

[16] N. Nurmi, "Membangun Website Sistem Informasi Dinas Pariwisata," Edik Inform., vol. 1, no. 2, pp. 1-6, 2017, doi: 10.22202/ei.2015.v1i2.1418.

[17] G. Alcianno, "Sejarah dan Perkembangan Internet Di Indonesia Alcianno Ghobadi Gani, ST.," J. Mitra Manaj., vol. 5, no. Cmc, 2020.

[18] A. B. Silviana and F. Thalib, "Pengembangan Situs Web sebagai Wadah Berbagi Jurnal Menggunakan Framework Codeigniter," no. 100, 2018.

[19] M. R. N. Yusuf, Y. A. Pranoto, and F. X. Ariwibisono, "Rancang Bangun Sistem Informasi Geografis Pemetaan Upah Minimum Kota (Umk) Dan Biaya Kebutuhan Hidup Di Provinsi Jawa Timur Berbasis Web," JATI (Jurnal Mhs. Tek. Inform., vol. 4, no. 2, pp. 247-253, 2020, doi: 10.36040/jati.v4i2.2722.

[20] E. Orlando, "Aplikasi Pengajuan Cuti Pada Human Resource Management Menggunakan PHP dan MYSQL (Studi Kasus Pada PT. INTILOKA)," J. IIm. KOMPUTASI, vol. 16, no. 3, pp. 275-284, 2017. 